\title{
Environmental impacts caused by the tourist industry in Elafonisos Island and the Neapoli district, Greece
}

\author{
B. S. Tselentis ${ }^{1}$, D. G. Prokopiou ${ }^{1}$, D. Bousbouras ${ }^{2}$ \\ \& M. Toanoglou ${ }^{3}$ \\ ${ }^{1}$ Department of Maritime Studies, Laboratory of Marine Sciences, \\ University of Piraeus, Greece \\ ${ }^{2}$ Hellenic Ornithological Society, Greece \\ ${ }^{3}$ Euroxenia Hotel Management and Consulting, Rhodes, Greece
}

\begin{abstract}
Many studies have shown that a tourist service or product is a blend of ecological, social and economic sub-systems, operable in the area of interest. Carrying capacity assessment has become an indispensable tool for formulating policy and strategies in the tourist industry worldwide. It is well known that Greece depends heavily on the tourist trade. For the Greek coastal tourist industry, the environment, both natural and man made, plays a leading role in the sustainable development of this economic activity. It is the purpose of this paper to apply novel environmental protection tools in order to estimate impacts inflicted by the tourist industry on local fauna and flora, as well as the whole well being of the physical environment.
\end{abstract}

\section{Introduction}

The concept of sustainable tourism is used in the context of achieving economic growth without damaging the natural and build environment as well as conserving the culture of local communities [1].

The World Tourism Organisation (WTO) defines carrying capacity as: "The maximum number of people that may visit a tourist destination at the same time, without causing destruction to the physical, economic, socio-cultural environment and an unacceptable decrease in the quality of visitors' satisfaction". 
Tourism can generate both positive and negative environmental impacts, depending on how well development is planned and controlled [2].

This paper investigates the level of impacts in two areas. The first district is situated on the southern part of the Peloponnesus peninsula and covers the Vatica municipality area, called Vatica. The other area is Elafonisos, a small island close to the Peloponnesus mainland $350 \mathrm{~m}$ from the Vatika coast.

Both places are well known tourist destinations with beautiful beaches, and sand dunes rich in spectacular flora. The importance of these areas for the Mediterranean ecosystem and biodiversity, is highlighted by the fact that they both belong to the NATURA 2000 network, which presents a special challenge for further tourist development of the area.

\section{Tourist development and environment}

Both areas of the study area, Vatica and Elafonisos, belong to the Prefecture of Laconia, with Sparta as the capital; capital of Vatica is Neapoly town.

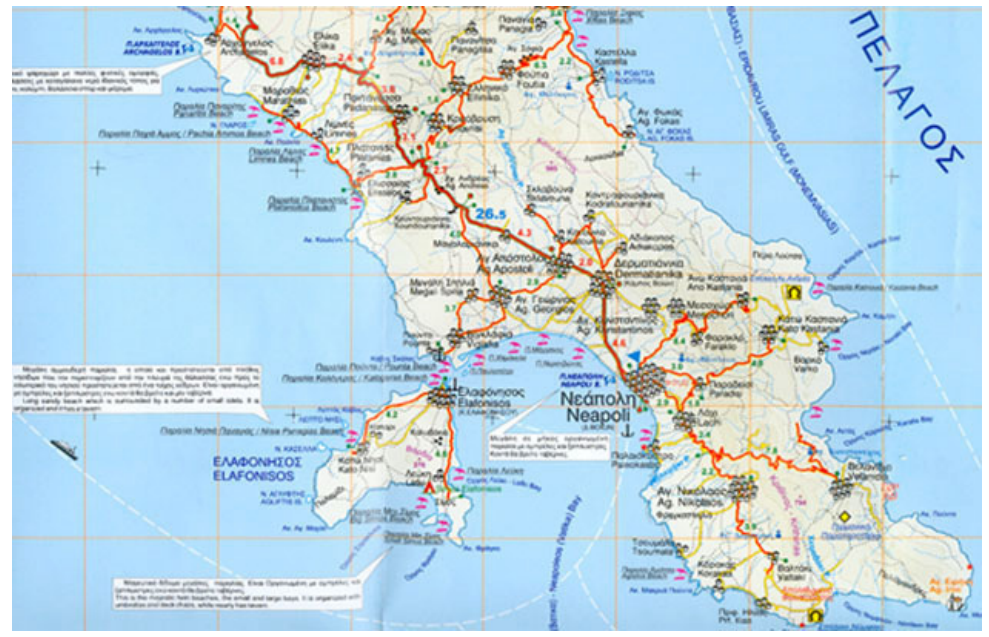

Figure 1: $\quad$ Elafonisos and Vatica [3].

In Elafonisos and Vatica, the tourism industry relies mainly on rooms to let and organized camping especially in Elafonisos. Some years ago free camping was still allowed and thus the area came to be associated with that kind of tourist service, even though that activity is now prohibited due to environmental protection reasons. Elafonisos is a very famous tourist destination but high season there is only August.

Tourist development started in the 90s (after 1985) and as a result there are no large tourist developments. Tourist services are based on small enterprises and, until recently, no serious treats to the environment have been sited. However, a steady increase in the number of visitors, and the realisation that the environment 
may well be in danger, have made it imperative to further study and estimate the adverse effects and propose policies and measures that will allow sustainable development in the area.

\section{Basic population characteristics [4]}

Table 1 indicates the population in terms of inhabitants and urban settlement characteristics. Both the areas under study are considered sparsely inhabited with Elafonisos showing a very small built up area.

As indicated in Table 2 the population of Elafonisos has increased considerably during the period between 1991 and 2001, a rise of about $15 \%$. The population of Vatica municipality has reduced slightly during the same period.

Table 1: $\quad$ Population.

\begin{tabular}{|l|c|l|l|c|c|c|}
\hline \multicolumn{2}{|c|}{ POPULATION } \\
\hline Area & Population & $\begin{array}{l}\text { Area } \\
\left(\mathrm{km}^{2}\right)\end{array}$ & $\begin{array}{l}\text { Density } \\
\text { inhabitants/ } \\
\mathrm{km}^{2}\end{array}$ & $\begin{array}{c}\text { Built up } \\
\text { Density } \\
\text { buildings } \\
/ \mathrm{km}^{2}\end{array}$ & $\begin{array}{c}\text { Built } \\
\text { up } \\
\text { areas } \\
\mathrm{km}^{2}\end{array}$ & $\begin{array}{c}\text { Mean } \\
\text { age of } \\
\text { built up } \\
\text { areas }\end{array}$ \\
\hline $\begin{array}{l}\text { Municipality } \\
\text { of Vies } \\
\text { (Vatica) }\end{array}$ & 7.871 & 215,6 & 37 & 2,25 & 3,5 & 1,62 \\
\hline Elafonisos & 745 & 20 & 36 & 2,48 & 0,3 & 1,5 \\
\hline
\end{tabular}

Table 2: $\quad$ Population trends.

\begin{tabular}{|l|l|l|l|l|}
\hline \multicolumn{5}{|c|}{ POPULATION TRENDS } \\
\hline & 1971 & 1981 & 1991 & 2001 \\
\hline $\begin{array}{l}\text { Prefecture of } \\
\text { Laconia }\end{array}$ & - & - & 90.522 & 92.811 \\
\hline $\begin{array}{l}\text { Municipality of } \\
\text { Vies (Vatica) }\end{array}$ & - & - & 7.257 & 7.111 \\
\hline Elafonisos & 586 & 611 & 647 & 746 \\
\hline
\end{tabular}

\section{Tourist enterprise history [5]}

As indicated in Table 3 hotel bed capacity in Laconia Prefecture has increased considerably during the period of 1995-2003.

Tourist development in Vatica and Elafonisos started in the early '90s. In 1993, the number of hotels in Vatica was 7 whereas in 2007 rose to 6 . Table 4 describes the trend in hotel units and bed availability over the years.

Today, tourist capacity in beds is estimated at about 6000 in Vatica and 900 in Elafonisos. Figures give a graphical 
Table 3: $\quad$ Tourist accommodations over the years.

\begin{tabular}{|c|c|c|}
\hline \multicolumn{2}{|c|}{ TOURIST ACCOMMODATIONS: PREFECTURE OF LACONIA } \\
\hline $\begin{array}{l}\text { Prefecture of } \\
\text { Lakonia }\end{array}$ & Hotels and similar establishments & Other accommodation \\
\hline 1995 & 3.201 & 2.961 \\
\hline 1997 & 3.386 & 2.961 \\
\hline 1998 & 3.357 & 2.961 \\
\hline 2003 & 3.504 & 3.270 \\
\hline
\end{tabular}

Table 4: $\quad$ Bed capacity trends $[6,7,8,9,10]$.

\begin{tabular}{|c|c|c|c|c|c|c|c|}
\hline \multicolumn{8}{|c|}{ BED CAPACITY TRENDS: VIES AND ELAFONISOS } \\
\hline & \multicolumn{3}{|c|}{$\begin{array}{l}\text { Hotels and rooms to let } \\
\text { tourist enterprises }\end{array}$} & \multicolumn{4}{|c|}{ Beds } \\
\hline & 1993 & 2000 & 2007 & 1993 & 2000 & 2004 & 2007 \\
\hline Vatica & 7 & 4 & 6 & - & - & 342 & 600 \\
\hline Elafonisos & 8 & 8 & 8 & - & - & - & 1100 \\
\hline
\end{tabular}

\section{Natural environment}

In this study area two regions have been characterised as environmentally sensitive.

\subsection{Elafonisos}

Elafonisos is a famous island for its beautiful sandy beaches. The most famous beach is called "Simos" (figure 5), which has crystal blue waters and a unique sand dune environment. The island of Elafonisos is situated within the gulf of Laconia, at its most eastern part, very close to Punta beach. Elafonisos has a triangle shape and acts as protection for the Neapoli gulf [11].

\subsection{Vatica}

The NATURA 2000 area in Elafonisos island (figure 4), houses an important sand dune - wetland environment, and is a continuum with sand dunes situated on the opposite side on the Peloponnesus. These wetland areas are considered to be under threat as they lie along the coast line, where most of the tourist industry activity is based. Close to the sand dunes of the municipality of Vies an important wetland called Strogili is situated (figure 2). In this area an important coastal lily (Pancratium maritimum) inhabited in the sand dunes, now considered to be under extinction. Many important fauna and flora species inhabit these Sites of Community Importance (SCI).

The area of these two Natura 2000 network places is $603 \mathrm{ha}$ as they are entered in the 40 most important sand dune areas of Greece [12]. 


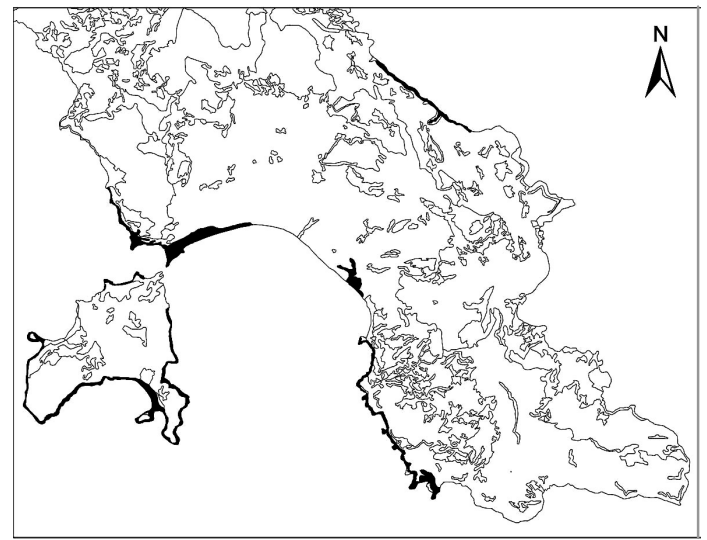

Figure 2: $\quad$ Sand dune areas and the salt marches opposite of Elafonisos.

Table 5: $\quad$ Local fauna [13].

\begin{tabular}{|l|l|c|}
\hline \multicolumn{3}{|c|}{ LOCAL FAUNA } \\
\hline & Species & $\begin{array}{l}\text { Threatened species mentioned in the 'Red } \\
\text { Book' [14] of Greek species }\end{array}$ \\
\hline Reptiles & 28 & 13 \\
\hline Amphibians & 2 & 0 \\
\hline Birds & 138 & 27 \\
\hline Mammals & 11 & 4 \\
\hline
\end{tabular}

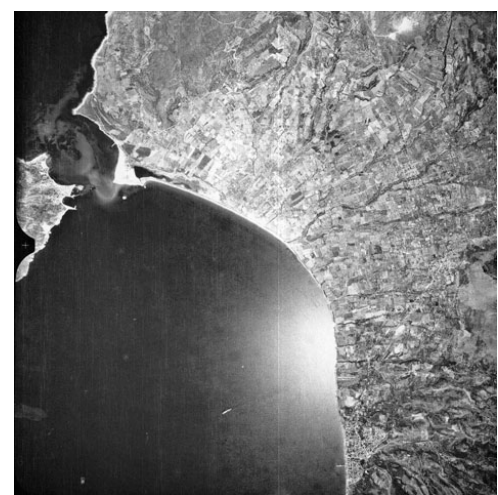

Figure 3: Vatica.

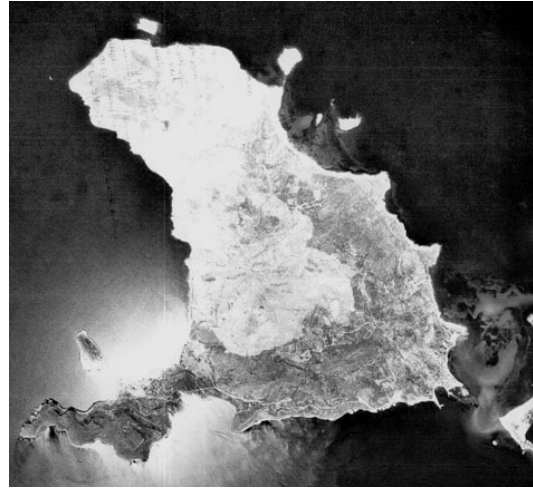

Figure 4: $\quad$ Elafonisos.

\section{SWOT analysis on tourism industry in Elafonisos and Vatica}

\subsection{Strengths}

Unique environment. 


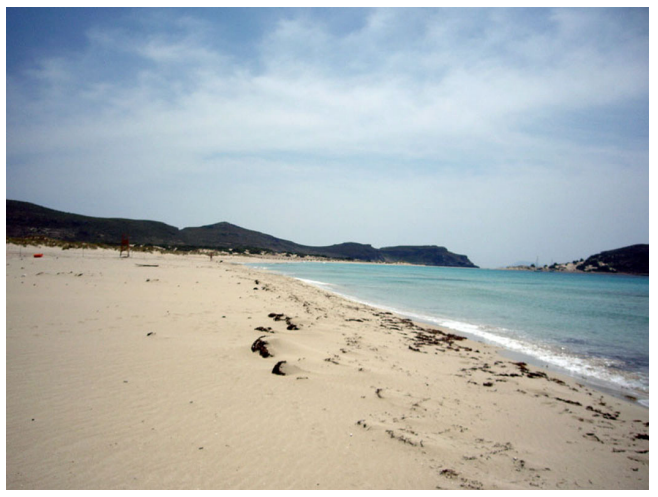

Figure 5: Elafonisos: Simos beach.

\subsection{Weaknesses}

No waste management system

Situated a long distance away from an airport. The nearer airport is on Kithira island and that of Sparta is a further distance but can be accessed via a road, giving it a marked advantage compared to the one on Kithira.

No organized tourist product

\subsection{Opportunities}

As the tourist trade started after the $90 \mathrm{~s}$, development can be planed in a sustainable way

Planning of an alternative tourist product based on local strengths and characteristics

\subsection{Threats}

No sustainable framework for development and illegal building practices, due to slack enforcement of planning policies and constraints, may cause serious impacts on the local physical and social environment.

\section{Environmental indicators}

\subsection{Beach impact factor}

With this indicator we analyse the pressures facing the coastal environment, as it describe the concentration of people visiting and using the facilities of the coastal area, and especially beaches.

Most of the tourists are concentrated around the sand dunes. The camping in Elafonisos is stated very close, about 30 meters from the sea. After camping some of the sand dunes are destroyed. The only way from the camping to the "Simos" beach is through the sand dune area as the same area is used as vehicle parking. 
Table 6: $\quad$ Beach impact factor.

\begin{tabular}{|c|c|c|c|c|c|c|c|c|}
\hline \multicolumn{9}{|c|}{ BEACH IMPACT FACTOR } \\
\hline $\begin{array}{l}\text { Municipalitie } \\
\text { s }\end{array}$ & $\begin{array}{c}\text { Beach } \\
\text { length } \\
(\mathrm{km})\end{array}$ & $\begin{array}{c}\text { Inhabit } \\
\text { ants }\end{array}$ & $\begin{array}{r}\text { Hotel } \\
\text { beds }\end{array}$ & $\begin{array}{c}\text { Rooms } \\
\text { to let } \\
\text { (beds) }\end{array}$ & $\begin{array}{l}\text { Total } \\
\text { beds }\end{array}$ & $\begin{array}{c}\text { Daily } \\
\text { visitors }\end{array}$ & $\begin{array}{l}\text { seasonal } \\
\text { populati } \\
\text { on }\end{array}$ & $\begin{array}{c}\text { Beach } \\
\text { impact } \\
\text { factor } \\
\text { (people } / \mathrm{km} \\
\text { of beach) }\end{array}$ \\
\hline Vatica & 4,5 & 7.871 & 400 & 900 & 1300 & - & 15.000 & 3333 \\
\hline Elafonisos & 7 & 745 & 50 & 900 & $\begin{array}{l}950+ \\
700 \text { of } \\
\text { campin } \\
\text { g seats }\end{array}$ & 1600 & 4.500 & 642 \\
\hline
\end{tabular}

\subsection{Waste management}

In Elafonisos and Vatica district, urban waste management (solid and liquid) is characterized by lack of an integrated management system, leading to inefficiencies and serious environmental threats. The situation in the area under study is depicted in Table 7 [15].

Hotels are obliged to install urban waste treatment plants in order to protect the environment from sewage leakage, especially to the sea. Other the municipalities in Greece have started building and operating such installations.

Table 7: $\quad$ Waste management.

\begin{tabular}{|l|c|c|c|l|}
\hline \multicolumn{4}{|c|}{ URBAN WASTE AND GARBAGE MANAGEMENT } \\
\hline & Inhabitants & $\begin{array}{l}\text { Urban waste } \\
\text { treatment plant }\end{array}$ & $\begin{array}{l}\text { Percentage } \\
\text { of waste } \\
\text { treated }\end{array}$ & $\begin{array}{l}\text { Garbage } \\
\text { management }\end{array}$ \\
\hline Vatica & 7.871 & No & $0 \%$ & Land fill* \\
\hline Elafonisos & 745 & No & $0 \%$ & Land fill* \\
\hline
\end{tabular}

*The land fills do not follow any of the E.U. specifications and are considered a serious environmental threat.

\subsection{Water pollution}

No serious problems of water quality are encountered in Elafonisos and Vatica. Sea water and drinking water quality is considered good with no signs of quality deterioration.

Table 8: $\quad$ Blue flags [16].

\begin{tabular}{|l|l|}
\hline \multicolumn{2}{|c|}{ BLUE FLAGS IN NEAPOLY AND ELAFONISOS } \\
\hline Vatica & 1 \\
\hline Elafonisos & - \\
\hline
\end{tabular}


Vatica has two beaches with Blue Flag certification, indicating that serious attempts have been made to protect the environment and possibly increase competitiveness in offered tourist services. Elafonisos, on the other hand, does not have any beaches with Blue Flag certification, a result that agrees well, with other indicators, presented earlier, showing a relatively not organized tourist development.

\subsection{Air pollution}

Neapoli and Elafonisos do not face serious atmospheric pollution since tourism is not of massive scale with relatively small vehicular traffic.

\subsection{Noise pollution}

Noise levels usually increase during the high season months, generated by an increase in the concentration of tourists, vehicles and tourist attractions.

\subsection{Visual pollution}

Recently serious efforts have been made in order to integrate local architectural character in new buildings and tourist infrastructure, in an effort to avoid serious mistakes of the past where speed, low cost and fast returns on investments, were the main criteria governing the building industry. One of the highlights is that due care has been paid to the design.

Table 9: $\quad$ Passenger arrivals and departures at Elafonisos port [17].

\begin{tabular}{|l|c|c|c|c|c|}
\hline \multicolumn{6}{|c|}{ PASSENGER ARRIVALS AND DEPARTURES IN } \\
\multicolumn{7}{|c|}{ ELAFONISOS PORT } \\
\hline Months/ Passengers & 2002 & 2003 & 2004 & 2005 & 2006 \\
& 17.268 & 40.679 & 15.661 & 20.674 & 28.257 \\
\hline June & 38.776 & 41.442 & 41.888 & 35.497 & 51.681 \\
\hline July & 67.322 & 44.505 & 80.287 & 75.467 & 84.233 \\
\hline August & 12.567 & 13.664 & 15.533 & 20.072 & 22.298 \\
\hline September &
\end{tabular}

Table 10: Vehicle arrivals and departures in Elafonisos port.

\begin{tabular}{|l|c|c|c|c|c|}
\hline \multicolumn{5}{|c|}{ VEHICLE ARRIVALS AND DEPARTURES IN ELAFONISOS PORT } \\
\hline Months/Vehicles & 2002 & 2003 & 2004 & 2005 & 2006 \\
\hline June & 6.185 & 13.695 & 6.555 & 5.345 & 8.481 \\
\hline July & 12.348 & 14.390 & 17.161 & 12.576 & 20.305 \\
\hline August & 21.692 & 16.638 & 31.698 & 28.408 & 29.243 \\
\hline September & 4.569 & 5.130 & 6.384 & 6.739 & 6.254 \\
\hline
\end{tabular}

\subsection{Overcrowding and congestion}

Overcrowding by tourists, especially at popular tourist attractions as Elafonisos can have serious impacts on the environment. About $\mathbf{5 0 0 0}$ tourists and 2000 cars 
visit the island daily. Taking into account that Elafonisos has no parking management, it is no surprise to witness, at high season, traffic jams, noise and increased air pollution.

\section{Conclusions}

Tourist development depends on the quality of the environment and the special characteristics that may attract visitors to the area. It has been proven, beyond any doubt, that in the long term uncontrolled development has serious impacts on the natural and build environment.

Environmental indictors, indicate that the transformation from a low quality, high-number (mass) tourist trade, to an alternative trade of high quality, is not easy especially when basic infrastructure units, such as waste management systems, town planning policies and building practices, government incentives etc. are lacking. It is a well known that such inadequacies have serious environmental consequences, and hinder any attempts towards developing a high quality tourist industry [18].

The increasing public interest in nature and landscape preservation is, today, considered to a major positive factor in the tourist development process. It is also well known, however, that the growing influx of visitors can exert strong pressures on fragile ecosystems [19]. Many proposals have been put forward to alleviate these side effects, and the concept of protected areas, such as national parks and reserves, are now an integral part of nature based tourism [20].

\section{Proposals}

- Planning is conceptually related to sustainable development [21]. It includes approaches to deal with development and economic options, to prevent environmental damage and to involve public and stakeholders in decision-making processes. It is proposed that serious efforts have to be made in the direction of formulating viable policies and developing tools for effective implementation and control.

- Due to the increased tourist demand it is suggested that all the areas with environmental interest must be governed by special organizational bodies [22] that, take account of the long term welfare of the local community and the environment. It is unfortunate that Greece lacks the framework and the experience in managing ecologically sensitive areas, even though the NATURA 2000 network has been active for several years. It is noteworthy that Greece has been accused and in some cases prosecuted at the European Court for not developing the governing bodies described in relevant EU directives.

- Free camping, which still takes place in areas with sand dunes in municipality of Vatica, causes serious impacts in the local flora and fauna. The development of high standard and quality organised 
camping areas in conjunction to the prohibition of the free camping could eliminate the impacts facing the sensitive sand dune ecosystem.

- Serious attempts must be made in order to protect the local fauna and flora especially when changes to the land use in Elafonisos and Vatica districts, are made.

- This study shows that the tourist industry in the Vatica district is far from organized and controlled. Serious attempts have to be made to ensure the development of a high quality tourist trade, based on alternative tourist products and services, mitigating the environmental consequences, highlighted above.

\section{Acknowledgements}

We would like to thank for their help and collaboration: Giannis Kousoulis, Mayor of Vion (Vatica), Vasils Stathakis, Vice mayor of Vion (Vatica), Haralambos Liaros President of the community (small municipality) of Elafonisos island, Sub Lieutenant Antonis Doumanis, Neapoly Port Authority, Dimitra Tselou, economist, Citibank Plc.

\section{References}

[1] Kamamba DMK, The challenges of sustainable cultural heritage/ community tourism. Second African peace through tourism, conference, Dar El Salaam 7-12 December 2003

[2] Lickorosh L. - Jenkins C., "An introduction to tourism" Butterwoth Heinemann 1997

[3] Map of Laconia, Nakas digital publications

[4] Greek National Statistics Organisation 2006

[5] Greek National Statistics Organisation 2006

[6] Tourist guide of Greece, 2000 ISSN 1107-9010 (in Greek)

[7] Prefecture of Lakonia, 2007 Polyodigos publications (in Greek)

[8] Municipality of Vies and Community of Elafonisos 2006 communications with questionnaires

[9] Mentis C., Elafonisos, Lafonisiotiki vivliothiki 1993 (in Greek)

[10] Municipality of Vies, general Plan, Horodinamiki, Athens 2004

[11] Prefecture of Laconia, Domi publications (in Greek)

[12] Oikonomidou E., The Greek Coasts, Hellenic Ornithological Society 1993 RSPB

[13] Bousbouras D. 2005. Research for nature environment of Municipality Vion, including NATURA 2000 area of Malea Peninsula, Strogyli wetland and island Elafonissos. 94 pp. Municipality Vion. (in Greek).

[14] Karandinos M. (ed.) 1992. «The Red Data Book of Threatened Vertebrates of Greece» Hellenic Zoological Society - Hellenic Ornithological Society, 356pp. (in Greek) 
[15] www.vatica.gr - "Vatika" newspaper, April 2007

[16] http://www.blueflag.org/ 11-5-07

[17] Neapoly Port Authority May 2007

[18] Prokopiou DG, Tselentis BS, Bousbouras D. and Toanoglou M "Carrying capacity assessment in tourism: The case of Dodecanese archipelago" The Ravage of the planet, First International Conference on the Management of Natural Resources, Sustainable Development and Ecological Hazards, Bariloche, Argentina 2006, Wessex Institute of Technology UKUniversity of Siena, Italy 12-14 December 2006 Bariloche, Argentina

[19] Papayanis T, 'Tourism carrying capacity in areas of ecological importance'

[20] M. Stone \& D. Smith “ An outline of Parks Victoria's tourism Partnerships Strategy and Challenges of Sustainable park tourism in Australia" International Conference on Sustainable Tourism Bologna 2006 Wessex Institute of Technology

[21] T. Fidelis, "Integrating environmental issues into the Portuguese planning system- 10 years of emerging challenges and persistent problems" Conference on sustainable planning and development Bologna 2005, Wessex Institute of Technology

[22] Prokopiou DG and Tselentis BS 'Proposals for sustainable development and Environmental protection for the island of Rhodes', Rhodes 2003 (in Greek) 